DOI: 10.1515/ijek-2016-0001

\title{
THEORY OF PATRONIZED GOODS. LIBERAL EVOLUTION OF PATERNALISM
}

\author{
Aleksandr Yakovlevich RUBINSTEIN ${ }^{1}$
}

\begin{abstract}
The neo-classical principles of rational behavior are considered in the context of the nature of paternalism as the basis of the Theory of patronized goods. The formation of society's normative interests is discussed in concern of political aspects. The article illustrates the theoretical and the practical aspects of the concept of consociation democracy, providing liberalization of the institutions for making political and economic decisions. The results of analysis reveal a pattern of paternalism drifting towards institutional liberalization. Proposed a hypothesis explaining why the economic policy in modern Russia still remains somewhere between archaic and merit paternalism.
\end{abstract}

\section{KEYWORDS}

patronized goods, rational behavior, merit paternalism, consociational democracy

JEL

C70, C72, D5, D6, D7, H41, Z28.

\section{INTRODUCTION}

Let me start from a preliminary note. In the present article the author attempts to combine a number of issues being the author's fields of research for the last 10-15 years to work out a common approach to create economic methodology of social liberalism. The idea is to further develop a concept of economic sociodynamics based on the complementary utility principle, postulating the social needs per se (Grinberg, Rubinstein (2005)), the Theory of patronized goods (Рубинштейн $(2008,2009 a, 20096))$, giving reasons for normative component of the social needs, and the institutions of market and political branches in making decisions concerning the social interest ((Рубинштейн (2011, 2012); Rubinstein (2013b); Гринберг, Рубинштейн (2013)).

Considering the development of the theory of patronized goods - from the principles of economic sociodynamic to the methodology of social liberalism - it is necessary to consider its basis, pointing out its special features and position in the economic theory. It is important to remind its key theses, and to show the positions it is ready to accept, as well as to give up (as opposed to the previous research) the following premises:

\footnotetext{
${ }^{1}$ Correspondence address: prof. Aleksandr Rubinštejn, DrSc., CSc., Ph.D., Institute of Economy, Russian Academy of Science, Moscow, Russia, email:arubin@aha.ru
} 
it gives up neo-classical principle of rational behavior and accept the Austrian methodological subjectivism (Machlup (1982));

$>\quad$ it gives up individualistic individual irrationality principle and accept individual behavior outside estimation having its own system of preferences (Grinberg, Rubinstein (2005));

$>\quad$ it gives up the idea of philanthropic state and accept the standards of the ruling party ideas (Laffont (2000)).

The present work continues the theoretical discussion about the theory of patronized goods, and it continues the discussion of theoretical issues in the articles «The theory of patronized goods in the optics of comparative methodology" (Rubinstein (2013b)) and «Social Liberalism: the problem of economic methodology» (Рубинштейн (2012)), which opened the discussion in the Russianlanguage journal «Social Sciences and Modernity» («Obshchestvennye Nauki I Sovremennost'»). This subject was the main topic at the XIV ${ }^{\text {th }}$ International Annual Conference «Leontieff Readings» (St. Petersburg, February 2015), where the author made a plenary report: «The theory of patronized goods and paternalism in economic theories: general and the specialties» (Рубинштейн (2015a)).

The debate, which took place in the «Social Sciences and Modernity» turned into a discussion of the state activities' motives that touched different aspects of theoretical economics. I emphasize that from the point of view of philosophy and methodology of economics, the discussion had again put forward the ideas of economic freedom and paternalism ${ }^{2}$ and its normative content. If you narrow paternalism to the boundaries of patronized goods, leaving aside the traditional (for this category) patriarchal aspects of state "paternal care" for its citizens, while avoiding both the negative connotation of the given concept and its social interpretation in the context of "social protection" or "support to the social sphere", the state activities per se remain in the center of research.

At the same time in contrast to the followers of classical liberalism, the supporters of its social variant, keeping their market economy positions, rightly state that it is not enough for the citizens to take their own effort to get their rights respected.

The economic philosophy of social liberalism is based on the very same notions about the economic systems as the concept of economic sociodynamics and the theory of patronized goods. According to these theories individuals willing to have their interests respected have to cooperate with each other and with the government, the late being responsible for realizing the interests of individuals and of a society as a community.

Here we find the generic features of the economic methodology of social liberalism supporting the individual initiative and the state activities with the aim to have the interests of an individual and a society implemented (or respected).

One should pay attention to the very special question, that clarifies the connection between state activities and paternalism: are there any state activities not connected with paternalism? From the point of the theory of patronized goods, this issue has no sense at all, as any state intervention in market relations, including the implementation of its economic, social or other policies basically has always certain normative "pater" settings. And in the context of this article, it does not matter what they are due to: the outcomes from the macroeconomic models, the pure political decisions, caused

\footnotetext{
${ }^{2}$ See the critical analysis of John Locke (Locke J. Works in 3 vol. Vol. 3. Moscow, 1988). Note that the term "paternalism" appeared at the close of the XIX century (Pique de Bry (1980)). It appeared again when the concept of paternalism was observed at the close of the XX century for the description of a special type of social and labor relations (Debouzy (1988), Noiriel (1988), Темниикий (2015)) and in the framework of behavioral economics, that proposed the concept of a libertarian or a new paternalism (Sunstein, Thaler (2003, 2008); Camerer et al. (2003)). See also (Лефевр (2008), Капелюшников (2013)).
} 
by the corresponding value preferences or the other reasons, including the tasks to liberalize economy.

The theory of patronized goods examines various aspects of the state economic activities concerning the market failures, public and merit goods, including the "Baumol disease" argument, etc. (Рубинштейн (2009), Rubinstein (2012, 2013a)). Concerning the repeating market failures and regular state failures, there are no conditions in the world for the self-regulatory mechanisms to work without failures, as well as there are no right state decisions that would eliminate the market failures and realize public interests. I will add that public goods always remain a motive for the state activities. Apparently, "the educational" state drive to bring the behavior of individuals to the certain socially desirable norms, will also never disappear (Якобсон (2016)), that the empirical studies of the merit goods and libertarian paternalism repeatedly confirm.

There is no appeal to paternalism in my reasoning (Тамбовцев $(2014$, c. 33)). These are the theories that explain the state activities, understanding that they always have a normative character, but these activities are not always aimed at the increase of a wealth of society (public welfare) and aggregated welfares of individuals. The situation is unlikely to change with a particular development scenario as well, when the individual, the state and the market will evolve according to the "collaborativism" (Полтерович $(2015$, с. 45-47)). Even in this optimistic case, it is probably impossible to do without the state activities that would take some other forms as well.

In other words the state activities, having a paternalistic content by its very nature, will forever remain the element of economic relations, and will never disappear, except, perhaps, in the dreams of anarcho-syndicalists and the followers of political individualism (Wyмnemep (1954)) or in the abstract models, where a set of certain ideal conditions is accomplished. At the same time, neoclassical theory, and its rigid basic conditions, does not give a satisfactory description of such state behavior. The search for an adequate explanation is directing us to a revision of its certain basic premises and to modification of the theory itself.

\section{IRRATIONALITY AND PATERNALISM}

Let me start with a fundamental condition of rational behavior, which combined the Austrian methodological subjectivism, according to which individual preferences are taken for granted, with the non-neoclassical assumption that each individual chooses the best option that optimizes his or her welfare. The rest is done by an "invisible hand", providing the welfare of society, that is by definition presented as an aggregate of individual wealth. If the losses in social wealth happen, they are explained by "market failures" and they account for government interventions to eliminate these losses. I'll not develop this well-known plot, but emphasize the main idea: a fundamental assumption of this theory is a strongly rational behavior of the individuals who maximize their welfare.

Regular critics of this "ideal condition" (simplifying abstraction) initiated probably by Thorstein Veblen, have accompanied the present ontological principle throughout its history. The first significant revision of this idea is associated, probably, with the works of John Katona (Katona (1951)), and Herbert Simon (Simon (1955)). H. Simon questioned the ability of people to correctly evaluate their choices (Simon (1955), Саймон (1993)). He also introduced a category "limited rationality" that has been rooted down in the economic literature (Simon $(1955,1957))$. Skeptical attitude to "rationality" postulate appeared after Simon's works. 
The weakening of this "ideal condition" was found in the theories of public goods and merit goods, and a "taboo" on irrational individual behavior was lifted. The theory of public goods acknowledged these "wrong" decisions only indirectly; that is why Paul Samuelson introduced a term "a false signal about the lack of demand for public good" to explain "free riding" (Samuelson (1954). Richard Musgrave later described the standard cases of irrational behavior in meritorics (Musgrave (1959); Musgrave, Musgrave, Kullmer (1994)).

Because of the special properties of public goods, individuals consciously conseal their preferences. As far as meritorious environment is concerned, the distorted signal of the demand (or about the demand) arises from the unrealized irrationality. Skeptical attitude towards the optimizing people behavior, no matter how to determine their interests, will actually bring to meritorics with the clearly expressed merit paternalism and interference into consumer preferences (Musgrave (1959, p.13), D’Amico (2009)).

In other words, in the theory of public goods and in meritorics, that both allow irrational behavior of individuals, one has to abandon Austrian subjectivism. Accepting the fact of irrational behavior, a researcher has to keep in mind the kind of behavior that could be called rational ${ }^{3}$. Such dichotomy inevitably leads to the two "valuation standards" and raises insolvable questions within the framework of the initial assumptions: what individual behavior should be considered a "true" preference, and is the actual behavior correlated to the one recognized as rational?

The well-known R. Thaler and H. Shefrin model adds nothing new here; the model postulates "split personality" which means that individual is simultaneously acting the two roles - of a week-will tempter's victim (me-executor) and of his or her rational antipode - role of "a Creator's pride" (meprogrammer). If the executor tends to act egoistically and shortsightedly, the "programmer" aspires to implement the long-term and enlightened interests (Thaler, Shefrin $(1981, \text { p. 392-406) })^{4}$. No matter how we explain this duality, I emphasize the main idea - the mere fact of lifting the taboos on irrational behavior, means neglecting the principle of methodological subjectivism, and a transition to a multiplicity of "I", that means actual legitimacy of paternalism aimed at support of that "I" which insures compliance with the normative settings of "pater".

It is quite natural that the theory of welfare, based on the individual rationality, believes that paternalism undermines the liberal doctrine. This is true to some extent, but only to the extent to which the principle of rational behavior are considered universal. Herewith, at the same time during the last 30-40 years the analytics in behavioral and experimental economy appeared, who (although in the laboratory) got a lot of empirical confirmations of irrational behavior of individuals. As a result by the beginning of XXI century there was quite a collection of behavior "anomalies", demonstrating individuals, who has occasionally made a mistake, but are also regularly making mistakes (Kahneman, Tversky (2000), Thaler (2000), Канеман, Тверски (2003), Павлов (2007, 2011), Капелюшников (2013)).

${ }^{3}$ Giovanni Dosi paid attention to the same point in a somewhat different context: I do not like the term "bounded rationality", it contains an allusion to a kind of "Olympic rationality ", from the heights of which we can judge how" limited is "what is limited" (Dosi (2012, p. 40)). It should be noted that the Austrian subjectivism rejects the notions of rationality and irrationality. "Human activities are always necessary to be rational. The concept of "rational action" is redundant and as such should be discarded" (Мизес (2005, c. 22)).

4 Published in "workbooks" (Shefrin, Thaler (1978)), this model dates back to an earlier study, where Richard Shiffrin and Walter Schneider, considering the hypothesis about the availability of two cognitive systems in humans, discovered "the struggle of mind with intuition", which is a prototype of the future models with multiplicity "ME"» (Schneider, Shiffrin (1977)). 
The new situation required an explanation of empirical facts that did not fit within the boundaries of the standard theory. It should be noted however that in this area behavioral economists merely continued the meritorious argumentation (Либман $(2013$, с. 32, 38)), based on the multiplicity of "I" reinforcing these arguments and turning them into their main methodological technic (Thaler, Shefrin (1981), Sunstein, Thaler (2003)). In other words, they also followed the track of rejecting the principle of "methodological subjectivism", thereby retaining and developing paternalistic trend in attempts to settle the contradiction between the theoretical assumption of rationality and the realities of irrational behavior.

I do not want to overestimate the scale of changes in the methodology of economic science. Some economists still quite reluctant towards revision of the assumption of individuals' rational behavior. The criticism of rationality on the part of meritorics and behavioral economics indicates some exceptions in the models of rational choice that, in terms of these theories, still need a deeper analysis and a new theoretical generalization.

But the main problem here is different, whether it is necessary to abandon the two components of rationality in explaining individual irrational behavior or not. I think it is not. Remaining within the frames of methodological subjectivism with a requirement to take the individual preferences for granted, it is still possible to seek a solution in a different interpretation of optimizing behavior. The case is that, from the perspective of methodological subjectivism, an individual is always based on his personal values and tastes, demonstrates the best behavior in specific circumstances. And if such behavior is regarded as irrational or limited rational, it means that an explanation comes from an external source, on the basis of its inherent standard. From the point of this source the people may not choose the best option, because of deficiency in knowledge, willpower and resources in meritorics. 5

At the same time, both meritorics and behavioral economics, and libertarian paternalism, that was produced by them (Sunstein, Thaler (2003, 2008)), as well as asymmetric paternalism (Camerer et al. (2003)) proceed from the assumption that the state, aimed at changing the developed circumstances, is able to improve, from the point of "pater", the quality of people's behavior, and to help them realize "the rightly understood interests" as well as to bring their preferences more in line with a certain normative standard. The leading figures of this trend see the main advantage of such a "push" policy («nudge») in the fact that it resolves the contradiction between paternalism and the freedom of choice (Sunstein, Thaler (2003, p. 1188)). Not completely supporting this statement, I

${ }^{5}$ I'll digress here for a short comment and I will note that, despite the Austrian verdict, de jure: "In the annex to the ultimate goals of the activities, the concepts "rational" and "irrational" are irrelevant and meaningless "(Мизес (2005, c. 22)), de facto Ludwig von Mises confirms the meritorious arguments of irrational behavior "Of course, needless to say, there will always be individuals or groups of individuals, whose intellect is so limited, that they are unable to realize the benefits, that social cooperation provides them with. Moral norms and will-power of the others are so weak, that they cannot resist the temptation to achieve the ephemeral advantages through the actions that are harmful to the smooth functioning of the social system. For individual adaptation to the requirements of social cooperation requires sacrifices. Of course, these sacrifices are temporary and imaginary, since, over and above, they are more than compensated by an incomparably greater benefits of a social life, or benefits, with which life provides in society. However, at a given moment, during the very act of rejection of the expected pleasure, they are painful, and not everyone can realize their future expediency and behave accordingly" (Мизеc (2005, c. 140)). In the page before Mises writes: "Utilitarian ... does not require from a person to give up his or her own well-being for the sake of society. He recommends him or her to realize what are his or her rightly understood interests" (Мизес (2005, c.139)). But still, how to be with those, who cannot realize the rightly understood interests and their future expediency? In this case, shouldn't it be the society that creates the conditions for the individuals to "behave appropriately"? 
would like to note that push policy itself (being a tool of meritorics) creates the conditions, under which an individual, by choosing the best option for himself or herself, implements normative standard, or is at least approaching to it. ${ }^{6}$

These considerations are to be continued and estimated from the point of game theory, which also considers the rationality principle. It is well known, that non-cooperative actions of individuals can bring them to a position that contradicts their individual objectives. However due to the "imperfect" game rules (institutional environment), rational behavior of individuals can lead to welfare losses (Майерсон (2010, с. 29)), i.e. to the empirically observed irrationality (Nash equilibrium). Herewith, changes in rules of the game, in accordance with the same paternalistic understanding of "as it should be", will push individuals to choosing such a dominant strategy, which would put their preferences in compliance with normative standard, provideв by Pareto efficiency equilibrium.

In other words, Nash's methodology males it possible with the basic premise of subjective rationality of individuals (as well as the same bases of paternalistic activity), replacing the idea of multiple "I" (inherent to meritorics and behavioral economics), with a provision about "inefficient institutional environment". Using Nash's methodology allows incorporating of all types of paternalism into the instruments of modernization of the institutional environment. At the same time the question of normative standard definition still remains unsolved, (how to generate "as it should be" knowledge) - the standard which, in fact, defines the character and specific directions of institutional modernization, that pushes individuals towards choosing the "right" strategy.

Let us discuss the initial assumptions of the theory of patronized goods, which claims to generalize the concept of market failures, theory of public goods and merit goods, including libertarian and asymmetric paternalism, including even some aspects of non-cooperative game theory - these are the theoretical constructs directly connected with paternalistic activities of state (Рубинштейн (2011)). We need to repeat the basic definition of patronized goods - these are the goods and services, in which the state has a normative interest. ${ }^{7}$ Here, in fact, we can see the relations between the theory of patronized goods and the specified concepts.

Note that, besides the general, there is something special in these theoretical constructions. Following methodological subjectivism in the theory of patronized goods, and considering the individual behavior "as given", I assume that individuals act subjectively rationally, including the situations, described by Musgrave and later by behavioral economists. Thus, at the same time, that in order to explain their behavior, there is no need to resort to an artificial hypothesis of doublethink.

The specific of the patronized goods' theory lies not in denying the preferences duality, but in a different interpretation of its nature. In my view, such a duality comes from the two different subjects with in their preferences, but does not include double thinking of an individual. The situation, described in meritorics and repeated in behavioral economics: when the individual often is unaware of his or her second thought, but the third party knows about it, - and this party, for the

${ }^{6}$ In a standard example of behavioral economists, a consumer has a choice between a comprehensive lunch and à la carte menu, (order from the menu). One is silent about the basis a comprehensive lunch is formed (regulatory standard), to which consumer is pushed. Here in the mild form the preferences are imposed on an individual.

7 The theory of patronized goods, following meritorics, analyses such goods as drugs or alcohol an individual demand for which is limited by the state. I will also note that state normative settings not always provide the public welfare. There are too many evidences of that in history. My focus is on the other point. At this point the theory of patronized goods (Rubinstein $(2013 \mathrm{~b}, \mathrm{p}$. 2223)) is virtually the same as the positions of the Austrian school: "The evil from bad ideology, needless to say, is much more destructive for the individual and for the society as a whole, than the drugs" (Мизес (2005, с. 687)). 
sake of individual happiness, stimulates this very idea, suffers a fundamental fail. One principle of the Roman private law states: the wish cannot be claimed unfair - «volenti non fit iniuria».

Based on this assumption the theory of patronized goods gave a different interpretation of preferences duality. The basis of this theory is methodological subjectivism, according to which the individual behavior should be interpreted "from an individual point of view - as something what a person craves for, because in his eyes it is desirable" (Мизес (2005, c. 24)). At this point the theory of patronized goods allows for an external source of evaluation, an autonomous source of normative standard.

Concluding the discussion of theoretical aspects of paternalism, we return to the famous formula: paternalism appears there, then, and insofar, where, when and since individual behavior is treated as irrational, or the institutional environment in which an individual operates, turns to be inefficient. But the question remains: what is an external source of evaluation, that defines this irrationality and inefficiency; and how the institutions provide for the normative "pater" settings, acting on behalf of society and declaring the preferences as the public interest?

The economic theory examines the two main versions of the public interest. First, it is the market coordination of individual behavior, and the formation of the cumulative (social) interest. Second, it is the autonomous social preference, which is not reduced to the preferences of individuals (Grinberg, Rubinstein (2005)). The theory of patronized goods accepts two sources of social preference, - market and politicy. So, there are normative settings, that determine the nature and the essence of paternalism (Rubinstein (2013b, p. 18-19)).

Considering the state as a "politically aggregated individual" (Автономов (2014, с. 55)), implementing normative interest of the society, one should not forget R. Boudon's verdict, who emphasized that these assumptions are valid only in case, if the individual is "... endowed with institutional forms enabling collective decision making» (Boudon (1979)). Thus, the obvious factor of a utility function for a "politically aggregated individual" is a certain institutional system, allowing him to take decisions on behalf of the society.

\section{DON'T DODGE BEHIND THE MAJORITY}

Starting with Aristotle, social and political philosophers were looking for a solution to this problem in the institutions of representative democracy. According to Aristotle, such an institution was "republic"; there the ruling was carried through decisions, the right to make them was delegated to the special people (Аристотель (1983)). Those were the ones whom Plato, Aristotle's teacher, called "philosophers" (Платон (1971, с. 275)). Much later in the other epoch, Musgrave called those "philosophers" "an informed group of people" (Musgrave (1969, p. 16)), and still later Schmidt called them "politicians" (Schmidt (1988, p. 384)). Those were individuals who had ideas of "as it should be", and who were able to articulate their views on behalf of the society. Characterizing such people, Aristotle stressed that "participation in the political life - is a privilege of the few are who were equal to each other, but unequal to the other residents of the polis, those were free citizens. «These people, unequal to the other individuals, we shall call the politicians. They as the subjects of collective decisions, will form normative interests for the whole society, later addressed to all "the citizens"».

Considering the normative interests of a society, it is necessary to answer the main question. If a particular interest cannot be represented in the form of aggregate of individuals' preferences in the market branch, what are the mechanisms of its creation in the political environment? Trying to answer this question in discussing the interests of social integrity, I precede from an already 
indicated problem - determining factors of the formation of the utility function for a politically aggregated individual. It is quite likely that the understatement of this issue in my previous articles, led to misunderstanding of the concept of economic sociodynamics (the CES) and so misunderstanding of the theory of patronized goods in the economists, attributing almost metaphysical nature to these theories.

The point is that if we consider political branch of the formation of normative interests for a society (justifying their autonomy and not reducing them to the individual interests) as a participant in generation of public interest, revealed by a market mechanism, it all does not mean that the normative preferences of a society are defined by some mystical body. Of course, not. As in case with the market branch, and also in the society's interest sui generis, special people are involved, the politicians - in cooperation between themselves and the current institutions.

Moreover, if in the market environment, an individual is able to evaluate the available alternatives from the point of his or her own benefit, the political branch generates alternatives, associated with the normative understanding of the social welfare. So it is about the "other events". For example, if in the market environment, an individual decides, whether he (or she) would go to the theater or buy apples, in the political environment the politicians face another alternative: what is more important - whether to support familiarizing the population with the theater, or to promote the consumption of fruits. In other words, in the political process of shaping the public interests, in contrast to the market branch, one needs to consider the "other events".

It is necessary to consider the "other behavior" as well, because, unlike individuals, preferences of "politicians", 8 who are not equal to the individuals, acting on behalf of the society, are caused basically not by the personal, but by the public funds. Many facts ${ }^{9}$ point to the possibility of lower evaluation of the public resources' utility for the people, making decisions about the directions of public expenditures as compared to their own funds. Taking this notion into account, and quite agreeing to the actual state of things, the activity of a state is to implement the normative interests of a society. And this interest is determined by collective decisions of the politicians concerning the features of their individual behavior.

The theory of patronized goods confirms a widespread outcome that any form of paternalism strengthens the state, which, as a rule, is drifting towards "Leviathan" state. Here the state activity may impose losses on individuals and their groups and cause a loss to an aggregate welfare. This situation raises the question about liberalization of the processes of making collective political and economic decisions, and about the redistribution of powers in favor of institutions of civil society. In this article, we consider the institutions, that would weaken the monopoly power of the ruling majority or would not allow its manifestation.

It should be emphasized that collective solutions, generated by the political branch, in contrast to the market mechanisms of self-regulation, should be considered as the result of a discourse, determined by the established institutions and the interests of the power elites, capable of both bringing closer and move away the public option from the real needs of society (Тихонова $(2013, c$. 41-43), Уронов (2014, с.26)).

${ }^{8}$ I quote Yacobson, who emphasized "the difference of social policy, which a small circle of property and power resources owners, implements to the majority, - the people deprived of these [resources], as compared to the policy that is carried on the basis of the representation of interests and preferences of the majority, possessing all the resources," Якобсон (2016, с. 5))

${ }^{9}$ This genetic fail in public funds often distorts the politicians' motivation. Many authors write about it, concerning the allocation of the budgetary funds to financing the public goods and the rent, assumed by political and economic elites, both seeking to preserve and even to increase the rent. 
The remark, that the "political process has its own logic, in many cases, this logic in many cases does not coincide with the usual logic of optimizing economic mechanisms", is also true (Рadblzuн, Энтов (2012, с. 26)). It should be also noted tgat in the recent past there dominated the concept of "benevolent (or "beneficent") state", whose activity was aimed exclusively at implementing the actual public interests. But in the second half of the 20th century, a thesis of a displacement of public choice and the associated political decisions in favor of the ruling elites has started playing an increasingly important part (Stigler (1971)).

The given conclusion corresponds with another thesis of the theory of patronized goods, associated with a widespread point of view, according to which the true ("authentic") interest of a society always differs from the public choice, realized through the parliamentary procedure (Лаффон (2007, c. 23)). In other words, the political elite offers "the action program" correlating with the interests, recognized by the political system, - that is the functioning institutions and individuals, including political and economic elites, as well as the parliament and its powers. These interests are becoming normative interests of the whole society as a result of the relevant collective decisions.

The authors of lots of the articles were examining various aspects of a collective decision-making, including the public choice theory and the new political economy. Their common idea is a parliament as a totality of politicians - as the individuals, participating in decision-making and finding solutions, through various voting procedures (the principle of unanimous voting; the principle of qualified or simple majority). Thus, the parliament with its different factions (groups), formed by the opposition parties, influences only on the process of discussion that precedes the vote, but does not affect its results. So, the parliament is most often considered a totality of the groups of politicians, defining normative interests of the society, corresponding to the majority of deputies' votes.

Here it is necessary to pay attention to a fundamental contradiction, characteristic of the modern political process. On the one hand, every democratic system implies the supremacy of the majority, while on the other - the subordination to the majority is often transformed into "dodging behind the majority". ${ }^{10}$ In consent with a preference of "the many" and evading behind these "many", an individual risks to miss the correct choice. The whole of society is at risk: pushed by the democratic majority, it may be out of range of effective solutions. There are many examples to confirm this idea. Often, too often, our history shows an absolute failure to coincide the interests of the "many" to those who were "right".

Here I quote the words of Mises: "Today, even many of those, who support democratic institutions, ignore these ideas. ... They forward the arguments in favor of freedom and democracy, but these ideas are infected with collectivist errors; their doctrines are rather misinterpretations than a support to genuine liberalism. According to their ideas, the majority is always right simply because it is able to crush any opposition; the majority rule is the dictatorial power of the largest party, and the ruling majority should not limit itself, exercising its authority and implementing its policies. .... Such pseudo-liberalism is completely opposite to the liberal doctrine" (Мизес $(2005$, c. 144)). It is difficult to oppose this, but the problem of institutional liberalization is crucial for the theory of patronized goods, dealing with the paternalistic activities of the state.

10 "It is not difficult to resist the persuasions and influence of one villain, but when a crowd of them is rushing downhill with an irresistible impetuosity, then failure to appear in a stream is a sign of a noble soul and mind, brought up courageously» (Philo. De spec. Leg. IV, 45-47quotation according to Ковельман (1996, с. 65)). These words with modern content belong to Philo of Alexandria - a philosopher of 1st A.D. The meaning is important, interpreted by Philo in elliptic form. 
Limiting the ruling majority and protection of the opposition minority are the initial guidelines of the theory. It deals with creating the institutional conditions for an individual to keep his voice, and not to «dodge behind the majority». ${ }^{11}$ More than that: regardless of the mechanisms of forming the public interest, (it may be a private decision of a group leader or a vote of all the members of a group, or a compromise solution of several groups (a coalition)), the public interest is always determined in the form of normative settings. Thus, herewith, the normative interests (according to the level the society and its political system are developed) concern preferences, reflecting the values and ethics, and the other social and economic settings, found in the programs of political parties and public movements of different social groups.

In other words, normative interests, generated by a political branch, are considered the value judgments, generated by "expert on ethics" (Samuelson), or "true preferences» according to the representatives of meritorics and new paternalism (Musgrave (1957, 1994), Brennan, Lomasky (1983), Tietzel, Muller (1998), Thaler, Sunstein (2003, 2009)). But I stress again: adequacy of these value judgements to the interests of society correlates to the level of the development of society and its political system. And most importantly, too often these interests involve the risk of making subjective (wrong) and not always positive (from the point of society) decisions (Мельник, (2015, c.16)).

The state activity is aimed at eliminating the market failures, but it will impact the political situation as well. Moreover, this effect, shown by Daron Açemoglu and James Robinson, may be destructive as well, contributing to inefficiency of economy (Асемоглу, Робинсон (2013, с. 17-19)). The general provision about insolvency of "the starry-eyed", "idealistic" and widespread thesis that "good economics is also good politics", is correct as well (Норт, Уолис, Вайнгаст (2011)). Note that the parliamentary party (coalition), having the majority of votes, is able to carry through ballot practically any decision in its interests. ${ }^{12}$ And it's not just. And it does not matter, whether a parliament is representative and whether its work is properly organized. An important component of electing ("a good parliament") is the decision-making procedure and the institutions, that are behind it (Мельник, $(2015$, с. 18)).

The alternative concepts appeared and later dominated at the end of the century. Among them were the studies by Jean-Jacques Laffont, who emphasizes that, "in spite a domineering of an idea that public interest is the decisive one when choosing a direction of development," there appeared and gained momentum a "theory of interest of groups", with a particular emphasis on their impact in shaping political decisions" (Лаффон (2007, c. 23)). Analyzing this trend, Laffont considers an "authentic adviser" to the ruling party, who offers an action program, that increases party's benefits in the current economic and political situation" (Лаффон (2007, с. 22)).

In post-communist Russia, and especially in the 2000nd years, this process became especially clear: "...a strong conflict of interests between the public and the elites remains; the consequence of such a

${ }^{11}$ According to N. Tikhonova, relying on the results of the study, conducted in 2012 by the Institute of Sociology of the RAS (the Russian Academy of Sciences), "What do the residents of Russia dream about?", - the norm that "every person should have the right to defend his or her opinion, even in the case, if the majority has a different opinion". This notion is currently shared by more than three-quarters of the representatives of any age, income, education, profession or other social group" (Тихонова $(2013$, c. 38)). Unfortunately, the Russian people in reality seem to agree to the reverse proportion.

12 This phenomenon is characteristic of the countries with low level of development of civil society, democratic institutions and political culture (Полтерович (2002); Полтерович, Попов (2007); Полтерович, Попов, Тонис (2008); Хиллман (2009)). 
conflict is a shortage of institutions, observed at the present, and these are the public goods, serving the whole of society, and not only its privileged part (Полищук $(2013$, с. 41)).

At the same time, however, it is wrong to assume the idea of "the only possible choice". This choice always lies in the field of normative decisions, where social and economic settings are domineering, as well as the target references of the parliamentary majority. One way or another, but the society always faces a political arbitrary in defining normative interests, misinterpreting the real needs and current priorities of a society.

And if the theories of public and merit goods, as well as libertarian concept or asymmetric paternalism, do not deal with the problem of creating "pater" settings, or aim to increase the wealth (well-being) of a society, on the contrary - the theory of patronized goods places the last issue is in the center of a discussion and is the main subject of analysis through the prism of the parliament collective decisions. Thus, at the same time, the parliament itself is considered a group of "authentic advisers" to various political parties, representing the interests of different groups of voters.

This approach makes possible to apply K. Arrow's theorem of "impossible" (Arrow paradox) to a group of "authentic advisers" and to make a conclusion that it is impossible to agree on the preferences of parliamentary parties, except for the case of a dictator when everybody would vote just as he does. Real political practices in the democratic states show an important regularity: any parliament evolves towards a "collective dictator" in form of the ruling party or party coalition, possessing the necessary majority of votes for the collective decision-making. In this case, the votes of the opposition parties virtually have no effect on collective decisions, and therefore, with a certain degree of convention, can be considered following the position of a "dictator".

A consequence of such an interpretation is a conclusion about inadequacy of parliamentary vote, the result of which (simple and, in some cases, a qualified majority as well) may generate solutions that are irrelevant to the real needs and priorities of society, and ignore the preferences of small parties, and the interests of many millions of their electors. This conclusion may be applied to any procedures of "collective decisions" described by Boudon and against which Mises warned. These decisions led to a general distrust in paternalism and state activity in the majority of economists and political scientists. There are no doubts that the doctrine of beneficent state should be indeed rejected. Another question is as follows: what to do about it and in what way to develop the theory and practice?

There are two possibilities. First, one can search for illusory paths of getting free from state interference. On a theoretical level, it is connected with the old and new conceptions of anarchism, as well as with a construction of such models, in which individuals and market coordination of their activities ensure a growth of welfare of each individual and a society as a community. So a number of initial conditions have to be introduced into these models, abstracting from their reality. It is clear that, within the framework of such models, there cannot be any damage from state interference, by definition. This approach is consistent with the political individualism or the radical liberalism, but, for natural reasons, and it is rejected by the doctrine of social liberalism.

Social liberalism, close to the reality, provides for the second opportunity. The recognition of the inevitability of state activity and paternalism, keeping both positive and negative impacts of the regulatory systems "pater", virtually underlies any system of their formation. Thus, the emphasis on the consequences of state interference makes sense only if the analysis is searching the mechanisms to eliminate or reduce its negative effects.

In a society these tasks may be performed by institutions that allow "not to dodge behind the majority", providing the participation of the opposition parties, the non-systemic opposition and the individual citizens in shaping and implementing regulatory interests, at least partially neutralizing 
"the arbitrariness" of power and drifting the public option to the real social needs. In the theory of patronized goods, this provision of liberal democracy is formulated as a general principle of fair political competition in the collective decision-making, that does not allow "tyranny of the majority" happen.

Perhaps, V. Polterovich is right, and it makes sense to consider not a competition, but a cooperation (Полтерович (2015)). In fact, institutional-provision of fair competition of the parliamentary parties, representing various social groups in the society with different interests, may be considered a cooperation. The same position is shared by L. Yakobson, who is examining an increasing role of institutions in civil society (Якобсон $(2016$, с. 18)).

\section{INSTITUTIONS OF CONSOCIATIONAL DEMOCRACY ${ }^{13}$}

Let me quote words of the young Russian political scientists Mark Simon and Ekaterina Furman: "The traditional theories of liberal democracy are based on the fact that people, who are affected by these or those political decisions, must be able to participate in making these decisions ..." (Симон, Фурман $(2015$, с. 2)). This important remark points to a known contradiction between the liberal doctrine and the representative democracy, for only the "elected people" are involved in collective decision-making, possessing "the property and power resources", regardless of whether or not theirs decisions affect those who are not in the group.

Considering that modern society is composed of many strata with a broad spectrum of social groups and of inhomogeneous deputies' corps, representing their interests, it is difficult to assume a consensus between the "authentic advisers" in an interpretation of public good and a proper direction of state activity. A possible solution here, that would allow at least easing this contradiction, is the creation of institutions, defining the rules of interaction of the elites and of the relevant politicians, on the basis of the agreed compromise, proceeding from their goals and interests. This point is shared by many contemporary politicians (Ferejohn (2000, p. 79), Симон, Фурман (2015, с. 14)).

At the same time, it is rather difficult to reach such a compromise. A remark of A. Heywood is fundamental in this context, and it goes as follows: an inaccessibility of an essential consensus does not mean that there cannot be a consensus on the procedure - and that is a willingness to resolve contradictions through a conclusion of an agreement, in accordance with certain conventional rules (Heywood (2002, p. 10)). Actually, finding procedural consensus is exactly the task, facing researchers, working in the field of political institutions. There are many articles on the subject, describing different types of decisions. The same is with the other trends of research the aim of which was formulated in the known question by Vincent Ostrom: "Are we able to develop an operational version of self-controlling society instead of being content that we are ruled by a "state", and empowered by the government? (Ostrom (1991, p. 4)). A number of politicians, sociologists and economists are proposing their receipts (for example, Buchanan, Tullock (1962); Tsebelis (1990, 1995); Bueno de Mesquita, Smith (2012)).

Thus, at the same time, one of the leading British political scientists, B. Crick, noted that the conflict of interests between the participants of political process is ineradicable and "power sharing", or "disperse of power", becomes the only possible solution. (Crick (2000, p. 30)).

13 Consociationalism (lat. consociation - community) are institutions of consociational democracy - and that is "democracy of a community". Sometimes the principle of "disperse of power" (power sharing) is understood as the consociationalism. 
This important remark reflects a general approach, developed by the political science of the second half of the 20th century, according to which, attempts to create institutions, that implement the principles consociationalism, became a dominant field of researches. A special place here belongs to the fundamental theory of "the consociational democracy", developed by the American political scientist of a Dutch origin, Arend Lijphart; he proposed a system of political institutions for multicompound, multi-ethnic and sub-culturally divided societies (Lijphart (1977, 1999), Лeŭnxapm $(1997)) .^{14}$

"The theory of constitutionalism of Arend Lijphart - writes a Russian political scientist Joomart Ormonbekov, is a complete and sufficient concept, in the framework of which, a double phenomenon: vertical segmentation of society into separate groups of the population, according to certain common characteristics (religion, language, race, ethnicity, ideology) and the institutionalization of the negotiation process at the level of elite of the groups listed above (Оромонбеков (2007, с. 92)). To this I will add the following: in spite of the fact that the theory was created mainly to address issues of peaceful solution of conflicts in the multi-ethnic societies, history has shown that it possesses the potential to expand beyond the "multi compound, multiethnic and divided by sub-culture societies» (Halpern (1986); Нджоку (1999); Бондаренко (2008); Симон, Фурман (2015)). I will note, in this regard, it is also possible of apply the theory of "consociational democracy" to the inhomogeneous structure of the parliament, consisting of the representatives of various political parties, - the parliament reflecting the interests of the relevant social groups, that is, to the processes of formation of the settings of "politically aggregated individuals".

The main attention here should be paid to the institutional solutions proposed by Lijphart within his consociational theory, and which are, in fact, the basis of consensus on the procedure. We are talking about a big coalition, comprising the leaders of all the big parties; about the principle of proportional political representation in the appointment of officials and in the allocation of budget funds; about the right of mutual veto, which allows to reject the decisions, detrimental to the interests of relevant social groups; about the autonomy of segments, - situation most typical for countries with a federative structure, providing specific rights for the subjects of a federation (Lijphart (1977, p. 153; 1999), Лейххарт (1997, с. 60); Ормонбеков (2007, с. 95-99); Симон, Фурман (2015, с. 11)).

To a certain degree, each of these institutions can be used for solving the problem of the normative settings of society. Thus, the creation of a grand coalition involving the representatives of political parties, that had lost the elections, for controlling the country, in most cases, allows to overcome "the tyranny of the majority." Thus, at the same time, coalition solutions, that take into account the interests of the most diverse groups of the population, acquire particular importance for patronized goods, for the allocation of budget funds, when, strictly speaking, their volume and structure are being set as well. However, if a certain party gets a sufficient number of votes (in Russia, so far, it is the current history), and a coalition does not appear, then the problem of protecting the interests of minority is of particular relevance.

14 In his classic book «Democracy in Plural Societies» (1977) [translated into Russian (Демократия в многосоставных обществах (1997)] Lijphart introduced a concept of community or consociational democracy (democracy of a community). In his later works the author complements the category of "consociational democracy" with the notion of "consensual democracy", the analysis of which he outlined in his book "Patterns of Democracy» (1999). See also (Симон, Фурман $(2015$, с. 20)). 
Let us now consider only the practical aspects of theory patronized goods, and, what is more, an example of that sphere, where there are few of those, who have objections to the activity of the state "for the sake of the positive liberties" or "freedoms for... " (Берлин (2001, с. 51-52)). We consider here the humanitarian sector of the economy (culture, science and education), suffering from the well-known 'Baumol's disease, "which are in need of financial support from the society" 15 However, especially in this sector, where human capital is formed, the negative traits of paternalism, associated with the arbitrariness in the choice of the regulatory settings of the state, are manifested more often than in the other sectors of economy. The Russian practice is overfilled with such examples, while institutional liberalization is still a relevant task.

Thus, at the same time, the state, trying to reduce budget costs, had formed a common setting to the corresponding transformations in the humanitarian (science, culture, education) sector of economy. Unfortunately, the decisions and associated reforms were carried out unskillfully, as a rule, with poorly calculated consequences, and this had only complicated the position of manufacturers of the patronized goods. The result of these transformations was the deterioration of education, collapse of the Russian Academy of Sciences and "the sword of Damocles" of "optimization" hanging over the culture sector network, and the job cuts (Muzychuk, Rubinstein (2014)). All this makes us think about the need for institutional transformations, aimed at using the institutions of the consociational paternalism, in creating the normative settings.

First of all, I consider one of the key institutions of consociational democracy, based on the principle of proportional political representation. Besides, participation in executive power bodies of the representatives of various political parties, expressing the interests of the relevant social groups, the introduction of this institution can create very important and rather necessary mechanisms of influence of the expert community on the process of making political and economic decisions. The matter in question is a change in the rules of creating the already existing public councils at the ministries and departments.

In accordance with the principle of proportionality of political representation, politicians should be included in these councils, who belong to the opposition parties and to non-systemic opposition, as well as leading experts in the appropriate areas of the activities in a society. The empowerment of these public councils with real rights and media coverage of the results of their functioning, will allow to avoid many mistakes that had happened before and that continue to happen in the absence of civilian control over the activities of the executive power bodies.

Besides the principle of proportionality, the theory of consociationalism offers more stringent principles as well, ensuring a transfer of "collective decisions" from the sphere of vote to negotiations, preceding the vote, associated with the search of a compromise. We deal with institutionalization of the veto right - the one ensuring the rights of the parliamentary minority to participate in decision-making process and to protect the interests of their electorates. ${ }^{16}$ This institution also appears to be quite substantial for the patronized goods, because it enables to block decisions, leading to a loss of welfare of both individual groups of citizens and of the whole society. With such an institution in Russia, perhaps, a number of laws unfriendly to education, science, culture and health, would not have been passed.

${ }^{15}$ For more details see: (Рубинштейн (2005, 2012); Rubinstein (2012, 2013)).

${ }^{16}$ One can turn to the Tsebelis writings, where the author substantiates the concept of the "veto-voters" (Tsebelis (1990, 1995)). See also Pomiguev: "The "veto-voters" are the collective or individual actors, whose consent is necessary to change status quo. So, status quo is nothing else but the "present policy", - it may be a legislation, the changes in which depend on the unanimous voting of all the "veto-voters" (Помигуев (2014, c. 200)). 
Consociational proportionality principle also assumes the possibility of the budget funds' allocation, concerning the interests of various parties, including those that do not join the majority coalition and are in the opposition. A definite step in this direction could be a new procedure of "zero reading" (a stage preceding a standard procedure of taking budget decisions in the parliament), during which less than $85 \%$ of government expenditures are allocated, in which the representatives of all the parliamentary parties are participating. In the next readings, the opposition parties should be given an exclusive right to control the remaining $15 \%$ funds, directing the funds to fulfill requirements of social groups, represented in the programs of these parties (Рубинштейн $\left(2014\right.$, c. 509)). ${ }^{17}$ This new institution will extend (broaden) the negotiation process towards a search for compromises and, at least partially, transfer a number of collective decisions to a stage, preceding parliamentary voting.

The appropriate procedures of budget funds' allocation should go along Lijphart's theory of "consociational democracy" and in addition be based on the institutions of "veto" and "zero reading", that are the basis of "procedure consensus" as well. This is an institution of budgetary normatives, characterizing the minimum shares of budget expenditures to support different kinds of patronized goods and an institution of individual budget allocations, ensuring the direct participation of the citizens in decision-making affecting the conditions of their lives.

Concerning the budgetary normatives, I emphasize that, in conditions of an objective inability of the most manufacturers of patronized goods in the humanitarian sector of the economy to ensure market self-sufficiency, budget expenditures in this sector should be considered as the guarantees of public support in the form of state obligations, involving three types of economic entities: employees, participating in creation, preservation, distribution and consumption of the patronized goods; their consumers - the citizens of the country; institutions of science, culture and education.

I emphasize, that the humanitarian sector of economy, that needs protection from the never disappearing in Russia "residual principle" and from the constant readiness of the authority to give up budgetary support (for science, culture and education), the institution of budgetary normatives reveals another principle of consociational democracy, the purpose of which includes a support of a status quo and creation of stabilizing mechanisms (Ормонбеков (2007, с. 98)). The introduction of this institution in the practice of funding the humanitarian sector means, in fact, means obtaining the status of "protected items of the budget". This measure will provide at least the minimum guaranteed level of subsidies to science, education and culture. ${ }^{18}$

The budget of these sectors should be connected to another institution of consociational democracy - the individual budget appropriations (IBA). The essence of this institution is transformation of the citizens into the subjects of budget policy. It defines their direct participation in the development of normative settings of "a politically aggregated individual" and is about a corresponding allocation of budget funds (Рубинштейн (2014, с . 507-508)). The predecessor of this institution is the practice of a number of European countries to use a mechanism of "percentage philanthropy". According to this mechanism, each taxpayer decides to direct $1-2 \%$ of his income tax to the social and cultural needs at his choice (Fazekas (2000), Kuti, Vajda (2000), Кнач, Соборников, Тисленко (2010), Хаунина (2012, 2013)). ${ }^{19}$

${ }^{17}$ I would note that $15 \%$ is a ballpark figure. Its specific value depends on the share of votes of the opposition parties in parliament. Thus, at the same time, the indicated $15 \%$ can be distributed between the opposition parties in proportion to their "weight" in parliament.

${ }^{18}$ This institution had already existed in the culture, as one of the norms of "Fundamentals of the Legislation of the Russian Federation on Culture" (article 45), adopted in 1992. Later the Ministry of Finance suspended this Article, and in 2005 it was totally removed from the Law.

${ }^{19}$ We also remind about "the church tax" (Хаунина (2014, с. 200-205) and the practice of "participatory budgeting" (Keblowski (2013)). At the same time the procedure of "participative 
Of particular note is the fact that the institution of "individual budgetary appropriations", and partially "participative budgeting" allow to smooth a mentioned above chronic contradiction between the liberal doctrine and the representative democracy. Moreover, in contrast to the "participative budgeting", the choice of the citizens in the "individual budgetary appropriations" is final and does not depend on the decisions of the representative and executive powers. The procedure of "individual budgetary appropriations' provides managing a small part of the budgetary resources, thereby implementing the right of the citizens to decide independently, what kinds of patronized goods have the most value for them.

The introduction of this institution would create a regular source of support for cultural, scientific and educational activities. At the same time, its efficiency and amount of financial support to the humanitarian sector of the economy, would increase considerably, if one uses the strategy of "spend, without wasting, accumulate." The implementation of this strategy, based on a combination of the institute of individual budgetary appropriations with the endowment funds, would become an important step towards formation of the development budget of the humanitarian sector of economy and lowering its dependence on momentary decisions of the authorities.

\section{CONCLUSION}

The discussion on the pages of a journal of many economists, sociologists and political scientists, representing different scientific schools and world outlooks provides for the general conclusion: social liberalism and its attribute (feature) - paternalism - should be perceived as an integral component of the economic reality. And, although some authors are discussing paternalism only with negative connotations, yet the modern trend of theoretical and applied researches is associated with the new forms of state activity determining its economic policy (Яновский, Жаворонков (2013, c. 69)). In this context Musgrave's meritorics was continued by the libertarian (Sunstein, Thaler (2003)) and the asymmetric paternalism (Camerer et al. (2003)).

The theoretical analysis started a new agenda, associated with the need to correct institutional provision of paternalism in favor of the civil society and the redistribution of powers. In focus are the new institutions of cooperation (Полтерович (2015)), the development of civil selforganization, institutionalization of community groups (Якобсон (2016)), and the institutions of "power disperse" (Lijphart (1999)). In the theory of patronized goods, this new agenda has found substantiation in the concept of consociational paternalism (Рубинштейн (2015)).

The past discussion revealed a strong research capacity that could not be totally covered in the articles, published in the journal "Social Sciences and Modernity." I am sure this is not "the end of the story". The reports on researches of the subject will be appearing in the new publications. In particular the article "On what personal characteristics could economic liberalism rely on" V. Avtonomov showed a special continuation to the discussion. A comparative study of theorists of liberalism with different world outlooks (F. Bastiat, L. von Mises, F. von Hayek, W. Eucken and M. Friedman), brought to a conclusion: there are two properties of man - the value of freedom and a reasonable strive for material benefits are determining liberal economic policy. At the same time, according to the author: "Liberalism, based on the material benefits only, will inevitably turn into paternalism" (Автономов $(2015$, c. 22)).

budgeting" is found only at a local level; the mechanism involves ascertaining the estimate of population about the reasonable expenses of the budget in question, in an approval of which only the "elected people" take part. 
This conclusion has a general nature. One should not count on the "ideal type" of a person with an "absolute sense" of freedom, who does not conflict with the "material benefit" - that one should not escape the reality. Keeping this in mind we come to a conclusion that liberalism has a paternalist component. I also want to stress the opposite: in a society with a slave mentality, albeit a small doze of it, there is still a "natural disposition (tendency) to freedom". Like all extremes it is only a convenient metaphor. Perhaps, one should better think about the distribution of the "value of freedom" in space and in time. At the same time, this characteristic appears to be useful for social analysis. In particular, the scholars, involved in the study of reforms, should, apparently, take into account this characteristic. I even risk assuming, that many "institutional traps" can be explained by a lack of this "disposition (tendency) to freedom" in the institutions transplanted.

It also seems that the "value of freedom" allows us to take a different look at the varieties of paternalist policies as well, sorting them by this very special parameter.

I will not take into account the extreme position - archaic paternalism, but one can contend that the meritor paternalism (Musgrave (1969)) is present in a society with a great "sense of freedom". Within this concept, the subsidies, tax incentives for producers and transfers to the consumers provide people with a certain freedom of choice. In this sense, libertarian paternalism substantially widens the possibilities of a consumer choice. The authors optimistically claim that its "pushing policy" (so called «nudging»), "removes the contradiction between paternalism and freedom of choice» (Sunstein, Thaler (2003, p. 1188)).

The next step towards ensuring more freedom for the individual was made by another group of the authors for the "new paternalism". Those authors paid attention to the fact that state paternalist activities should not concern those who behave rationally: the "asymmetric paternalism" helps those whose rationality is bounded and does not harm more rational people" (Camerer et al. (2003, p. 1254)). On the basis of these discourses, and a parameter "value of freedom", we can make a summary table (Table 1) to put in order the varieties of paternalism. 


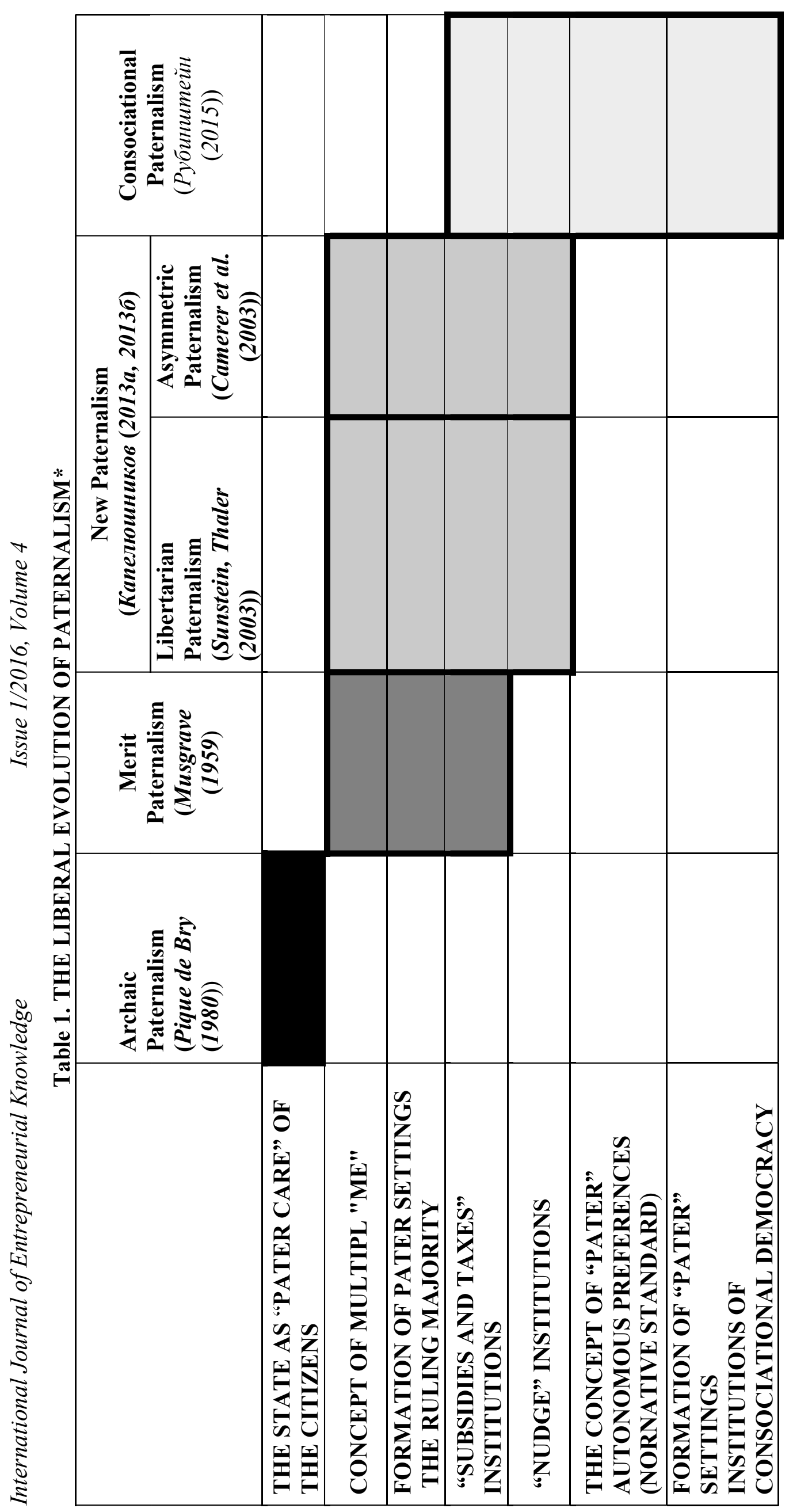


There is still another variety of paternalism, consociational paternalism, considered in the article (Рубинштейн (2015)). It differs from the meritorious and new paternalisms by its "connection" to the institutions of consociationalism (Lijphart (1977; 1999), Лeünxapm (1997)) ensuring the implementation of one of the fundamental principles of liberal democracy. The point is that "people, whom the political decisions are addressed to, are supposed to be able to participate in the process of decision-making" (Симон, Фурман (2015, с. 2)). In other words, the institutions of consociational paternalism provide liberalization of the formation of the normative settings, thereby widening the freedoms of people at a higher level, complementing their freedom of consumer choice.

If we also impose the proposed classification of the different types of paternalism, constructed according to the criterion of the "values of freedom" on the time axis, one may notice, that the development of different versions of paternalism turns out to be in order as well in time. This result allows us to formulate an important theoretical statement: paternalism, as part of the economic reality, is evolving in time and space, and is undergoing institutional evolution, in an evident liberal direction.

I emphasize again that we are observing only a certain theoretical trend. At the same time, real economic policy is not always based on the relevant institutional capacities. To compare this rend with the economic policy of a particular country, it is sufficient to use the same scale - "value of freedom." I once again quote Avtonomov: "... the possibilities of liberal policy vary depending on whether the "target" population has a stable and customary "value of freedom" (Автономов (2015, c. 22)).

If we consider the population of Russia, our country, I repeat the words of N. Tikhonova: «... in [his] mind, today in paradox unity coexist the values typical of liberalism, and a set of norms and values characteristic of "neo-etacratic societies"》 (Тихонова $(2013$, с. 38)). The practice of the last 20 years shows that the Russian people have readily agreed to the total domination of the state in all the activities of society. It means the population of our country does not yet have a fully developed and sustained "disposition to freedom", and this disposition can be found in not more than 15-20\% of the population (Авраамова $(2015$, c. 111)). This, of course, is a hypothesis, but it provides an explanation, why the economic policy in contemporary Russia is still somewhere between archaic and meritorious paternalism (Авраамова (2015)).

It is worth mentioning yet another Russian peculiarity, - a paradoxical relationship of liberal ideas with the methods of paternalism. This relationship is being manifesting in the economic policy for more than 20 years, often accompanied by many negative elements, characteristic of the archaic paternalism, when even the liberal ideas without a consociational selection, are transformed into the opposite ideas. Suffice it to recall voucher privatization or currency exchange regulation.

The positive expectations (and I believe it will turn out in reality) are well described by $\mathrm{N}$. Tikhonova: "Assessing the prospects for mass conscious evolution in the direction of liberal values, one cannot ignore the fact (these are the results of all the main research groups, ${ }^{1}$ involved in the analysis of the dynamics of norms and values) that... there is a general drift of the Russians from the normative and value systems, characteristic of the collectivist type cultures, to the individualistically oriented cultures" (Тихонова (2013, с. 39)). Perhaps, this drift, in not a too distant future, will create conditions for the institutional changes in the formation of the normative interests of society, and these changes will become a real driver of the transition from the archaic

${ }^{1}$ In particular, these are studies carried by N. Lapin and L. Belyaeva, V. Magun and M. Rudnev, N. Latova, N. Lebedeva and A. Tatarko, executed with the use of different techniques and various datasets. 
paternalism to the consociational paternalism, which (to my consent) is the nuclear of social liberalism in the $21^{\text {st }}$ century.

\section{REFERENCES}

Авраамова E.M. (2015) Есть ли в современном российском обществе запрос на социальный либерализм? // Общественные науки и современность. № 3. С. 101-113.

Автономов В.С. (2014) Еще несколько слов о методологическом индивидуализме // Общественные науки и современность. № 3. С. 53-56

Автономов В.С. (2015) На какие свойства человека может опереться экономический либерализм // Вопросы экономики. № 8. С. 5-24.

Аристотель (1983) Политика // Аристотель. Соч. в 4 т. Т. 4. М.: Мысль. С. 376-644.

Асемоглу Д., Робинсон Дж. (2013) Политика или экономика? Ловушки стандартных решений // Вопросы экономики. № 12. С. 4-28.

Берлин И. (2001) Философия свободы. Европа. М.: Новое литературное обозрение.

Бондаренко Т.Ю. (2008) Принципы консоциативной демократии в государственном строительстве за пределами Европы // Политическая наука. № 4. С. 213-223.

Гринберг Р.С., Рубинштейн А.Я. (2013) Индивидуум \& государство: экономическая дилемма. М.: Весь мир.

Гринберг Р., Рубинштейн А. (1998) «Социальная рента» в контексте теории рационального поведения государства // Российский экономический журнал. № 3. С. 58-66.

Дози Дж. (2012) Экономическая координация и динамика: некоторые особенности альтернативной эволюционной парадигмы // Вопросы экономики. № 12. С. 31-60.

Заостровцев А.П. (2015) Социальный либерализм: анализ с позиций австрийской школы // Общественные науки и современность. № 1. С. 64-74.

Канеман Д., Тверски А. (2003) Рациональный выбор, ценности и фреймы // Психологический журнал. № 4. С. 31-42.

Капелюшников Р.И. (2013) Поведенческая экономика и "новый" патернализм // Вопросы экономики. № 9. С. 66-90; № 10. С. 28-46.

Кнач Ю., Соборников И., Тисленко Д. (2010) "Процентная филантропия": о возможности введения в России налога на содержание некоммерческих организации. (http://tmbv.info/index.php?option=com_content\&view $=$ article\&id $=7323: 1-r-\&$ catid=331:2010 08-03-08-28-12\&Itemid=400).

Ковельман А.Б. (1996) Толпа и мудрецы талмуда. Москва-Иерусалим: Еврейский университет в Москве.

Лаффон Ж.-Ж. (2007) Стимулы и политэкономия. М.: ГУ-ВШЭ.

Лейnхарт А. (1997) Демократия в многосоставных обществах. М.: Аспект Пресс.

Лефевр С. (2008) Социальная роль предприятий в России: объяснительные возможности термина "патернализм" // Мир России. № 3. С. 149-170.

Либман А.М. (2013) Социальный либерализм, общественный интерес и поведенческая экономика // Общественные науки и современность. № 1. С. 27-38.

Майерсон Р. (2010) Равновесие по Нэшу и история экономической науки // Вопросы экономики. № 6. C. 26-43.

Мельник Д.В. (2015) Концепция социального либерализма на "рынке идей" современной России // Общественные науки и современность. № 2. С. 43-53.

Мизес Л. фон. (2005) Человеческая деятельность: трактат по экономической теории. Челябинск: Социум.

Нджоку Р. (1999) Что такое консоционализм? // Практика федерализма. Поиски альтернатив для Грузии и Абхазии. С. 300-312. (http://poli.vub.ac.be/publi/orderbooks/federal_r/12njoku.pdf).

Норт Д., Уоллис Джс., Вайнгаст Б. (2011) Насилие и социальные порядки: Концептуальные рамки для интерпретации письменной истории человечества. М.: Изд-во Ин-та Гайдара. 
Ормонбеков Ж. (2007) Теория консоционализма Аренда Лейпхарта // Казанский федералист. № 1-2. C. 98-108.

Павлов И.А. (2007) Поведенческая экономическая теория - позитивный подход к исследованиям человеческого поведения. М.: Институт экономики РАН.

Павлов И.А. (2011) Феномен "уклонения от двусмысленности" в теории рационального выбора. М.: Институт экономики РАН.

Платон (1971) Государство // Платон. Соч. в 3 т. Т. 3. М.: Мысль.

Полищук Л.И. (2013) Аутсорсинг институтов // Вопросы экономики. № 9. С. 40-65.

Полтерович B.M. (2015) От социального либерализма к философии сотрудничества // Общественные науки и современность. № 4. С. 41-64.

Полтерович B.M. (2002) Политическая культура и трансформационный спад // Экономика и математические методы. № 4. С. 95-103.

Полтерович В.M., Попов В.В. (2007) Демократизация и экономический рост // Общественные науки и современность. № 2. С. 13-27.

Полтерович В.М., Попов В.В., Тонис А.С. (2008) Нестабильность демократии в странах, богатых ресурсами // Экономический журнал ВШЭ. № 2. С. 176-200.

Помигуев И.А. (2014) Концепция вето-игроков: новый подход в изучении форм правления // Политическая наука. № 1. С. 199-210.

Радыгин А., Энтов Р. (2012) "Провалы государства": теория и политика // Вопросы экономики. № 12. C. 4-30.

Рубинштейн А. (2011) К теории опекаемых благ. Неэффективные и эффективные равновесия // Вопросы экономики. № 3. С. 65-87.

Рубинштейн А.Я. (2008) К теории рынков "опекаемых благ". М.: ИЭ РАН.

Рубинштейн А.Я. (2009а) К теории рынков "опекаемых благ". Статья І. Опекаемые блага и их место в экономической теории // Общественные науки и современность. № 1. С. 139-152.

Рубинштейн А.Я. (2009б) Мериторика и экономическая социодинамика: дискуссия с Р. Масгрейвом // Вопросы экономики. № 11. С. 98-109.

Рубинштейн А.Я. (2014) Методологический анализ теории опекаемых благ // Urbi et Orbi: в 3 т. Т. 1 Теоретическая экономика. СПб: Алетейя. С. 461-522.

Рубинштейн А.Я. (2005) Наука, культура и образование: препятствие или условие экономического роста? // Российский экономический журнал. № 4. С. 32-40.

Рубинштейн А.Я. (2012) Социальный либерализм: к вопросу экономической методологии // Общественные науки и современность. № 6. С. 13-34.

Рубинштейн А.Я. (2015а) Теория опекаемых благ и патернализм в экономических теориях: общее и особенное. М.: Институт экономики РАН.

Рубинштейн А.Я. (2015б) Экономический кризис и новая парадигма общественной поддержки опекаемых благ // Журнал новой экономической ассоциации. № 2. С. 264-269.

Саймон Г. (1993) Рациональность как процесс и продукт мышления // THESIS. Вып. 3. С. 16-38.

Самуэль Г. (2010) Либерализм. Опыт изложения принципов и программы современного либерализма. M.: URSS.

Симон М.Е., Фурман Е.Д. (2015) Проблема выработки политического компромисса: институциональное измерение. М.: ИЭ РАН.

Тамбовцев В.Л. (2013) Методологический анализ и развитие экономической науки // Общественные науки и современность. № 4. С. 42-53.

Тамбовцев В.Л. (2014) Общественные блага и общественные интересы: есть ли связь? //

Вопросы экономики. № 11. С. 25-40.

Темницкий А.Л. (2015) Патерналистские основы российской цивилизации в сфере труда // Социологическая наука и социальная практика. № 2. С. 51-69.

Тихонова Н.Е. (2013) Социальный либерализм: есть ли альтернатива? // Общественные науки и современность. № 2. С. 32-44.

Урнов М.Ю. (2014) Россия: виртуальные и реальные политические перспективы. М.: НИУ ВШЭ. 
Хаунина Е.A. (2014) От церковного налога к институту индивидуальных бюджетных назначений // Журнал Новой экономической ассоциации. № 4. С. 200-205.

Хаунина T.A. (2012) "Процентная филантропия" - дополнительный финансовый ресурс для организаций социально-культурной сферы // Журнал новой экономической ассоциации. № 2. С. 141-143.

Хаунина T.A. (2013) "Процентная филантропия" - проблемы трансплантации успешного института финансовой поддержки культурной деятельности / Культура и рынок. Опекаемые блага. СПб.: Алетейя. С. 127-132.

Хиллман А.Л. (2009) Государство и экономическая политика. Возможности и ограничения управления. М.: ГУ ВШЭ.

Шумпетер Й. (2001) История экономического анализа: в 3-х т. Т. 3. СПб.: Экономическая школа.

Якобсон Л.И. (2016) Социальная политика ювенального общества // Социальный либерализм (под ред. А.Я. Рубинштейна, Н.М. Плискевич). СПб. Алетейя. С. 294-309.

Яновский К.Э., Жаворонков С.В. (2013) Плоды социального либерализма и некоторые причины устойчивого выбора неэффективных стратегий // Общественные науки и современность. № 6. С. 61-74.

Agassi J. (1960) Methodological individualism // The British Journal of Sociology, no 3, pp. 24470.

Bueno de Mesquita B., Smith A. (2012) The Dictator's Handbook: Why Bad Behavior is Almost Always Good Politics. N.Y.

Buchanan J, Tullock G. (1962) The Calculus of Consent: Logical Foundations of Constitutional Democracy. Ann Arbor; University of Michigan Press.

Boudon R. (1979) La logique du sociale: introduction a l'analyse sociologique. Paris: Hachette.

Brennan G., Lomasky L. (1983) Institutional Aspects of "Merit Goods" Analysis // Finanzarchiv, vol. 41, pp. 183-206.

Camerer C., Issacharoff S., Loewenstein G., O’Donaghue T., Rabin M. (2003) "Regulation for conservatives. Behavioral economics and the case for 'asymmetric paternalism' // University of Pennsylvania Law Review, vol. 151, pp. 1211-1254.

Crick B. (2000) In Defense of Politics. Harmondsworth, New-York: Penguin.

D'Amico D. (2009) Merit Goods, Paternalism and Responsibility. Pavia. Universita.

Debouzy M. (1988) In the shadow of the Statue of Liberty: Immigrants, workers and citizens in the American Republic (1880-1920). Paris: Universitaires de Vincennes.

Fazekas E. (2000) The 1\% Law in Hungary: Private Donation from Public Funds to the Civil Sphere. The Journal of East European Law, vol. 7. no. 3-4, Columbia University e.g. on p. 447.

Grinberg R., Rubinstein A. (1999) Ökonomische Soziodynamik und rationales Verhalten des Staates. Köln.

Grinberg R., Rubinstein A. (2005) Economic Sociodynamics. Berlin, Heidelberg, New-York:

Springer-Verlag.

Halpern Sue M. (1986) The Disorderly Universe of Consociational Democracy // Western European Politics, vol. 9, no. 2. pp. 181-182.

Heywood A. (2002) Politics. L.: Palgrave Macmillan.

Kahneman D., Tversky A. (eds.). (2000) Choices, values and frames. N.Y.: Cambridge University Press. Katona G. (1951) Psychological Analysis of Economic Behavior. N.Y.: McGrow-Hill.

Keblowski W. (2013) Budżet Partycypacyjny: krótka instrukcya obsługi. Warszawa: Instytut Obywatelski.

Kuti E., Vajda A. (2000) Citizen's Votes for Non-Profit Activities in Hungary. Nonprofit Information and Training Center - Non-Profit Research Group.

Laffont J.-J. (2000) Incentives and Political Economy (Clarendon Lectures in Economics). Oxford (UK); N.Y.: Oxford University Press. 
Lijphart A. (1977) Democracy in Plural Societies: A Comparative Exploration. New Haven: Yale University Press.

Lijphart A. (1999) Patterns of Democracy. Government Forms and Performance in Thirty-Six Countries. New Haven: Yale University Press.

Machlup F. (1982) Austrian Economics // Encyclopedia of Economics. N.Y.: McGraw-Hill.

Musgrave R.A. (1959) The Theory of Public Finance. N.Y.-L.

Musgrave R.A. (1969) Provision for Social Goods // Public Economics. London-Basingstoke: MacMillan, pp. 124-144.

Musgrave R.A., Musgrave P.B., Kullmer L. (1994) Die öffentlichen Finanzen in Theorie und Praxis. Band 1, auflage 6. Tübingen.

Muzychuk V., Rubinstein A. (2014) Optimization or Degradation? Russian Culture between the Past and the Future. Social Sciences. No. 6, p. 13-31.

Noiriel G. (1988) Du patronage au paternalisme: la restructuration des formes de domination de la main-d'oeuvre ouvrière dans l'industrie métallurgique française // Le Mouvement social. Paternalismes d'hier et d'aujourd'hui, no. 144.

Ostrom V. (1991) The Meaning of American Federalism. Constituting a Self-Governing Society. San Francisco: ICS PRESS.

Perrot M. (1979) Le regard de l'Autre: les patrons françaivus par les ouvrièrs (1880-1914) // Le patronat de la seconde industrialisation, etudes rassemblèes par M. Levy-Leboyer. Paris: Éditions Ouvrieres.

Pique de Bry F. (1980) Le paternalisme dans l'opinion des industriels français du XIXem siècle. These d'Etat en Sciences Economiques. Paris: Université de Paris I. International Scientific Journal, no. 3, p. 36-58.

Rubinstein A. (2012) Studing «sponsored goods» in Cultural Sector Symptoms and Consequences of Baumol's Cost Disease. Creative and Knowledge Society / International Scientific Journal, vol. 2, p. 35-57.

Rubinstein A. (2013a) Studying «patronized goods» in cultural sector. Econometric model of Baumol's disease. Creative and Knowledge Society / International Scientific Journal, vol. 1, p. 2848.

Rubinstein A. (2013b) The theory of «patronized goods» in the optics of comparative methodology. International Journal of Entrepreneurial Knowledge, vol. 3.

Samuelson P.A. (1954) The pure theory of public expenditure // Review of Economics and Statistics, vol. 36, no. 4, pp. 387-399.

Schmidt K. (1988) Mehr zur Meritorik. Kritisches und Alternatives zu der Lehre von den öffentlichen Gütern // Zeitschrift für Wirtschafts - und Sozialwissenschaften. Vol. 108. Jahrgang. Helf 3. S. 383-403. Schneider W., Shiffrin R.M. (1977). Controlled and Automatic Human Information Processing I. Detection, Search, and Attention Processing II. Perceptual Learning, Automatic Attending and a General Theory // Psychological Review, vol. 84, no. 1, pp. 1-66; no. 2, pp. 127-190

Shefrin H.M., Thaler R. (1978) An Economic Theory of Self. Center for Economic Analysis of Human Behavior and Social Institutions. Working Paper No. 208.

Simon H.A. (1957) A Behavioral Model of Rational Choice, in Models of Man, Social and Rational: Mathematical Essays on Rational Human Behavior in a Social Setting. N.Y.: Wiley.

Simon H.A. (1955) A Behavioral Model of Rational Choice // Quarterly Journal of Economics, vol. 69, no. 1, pp. 99-118.

Stigler G. (1971) The Theory of Economic Regulation // Bell Journal of Economics, vol. 2, pp. 3-21.

Sunstein C., Thaler R. (2003) Libertarian paternalism is not an oxymoron // University of Chicago Law Review, vol. 70, pp. 1159-1202.

Sunstein C., Thaler R. (2009) Nudge: Improving Decisions about Health, Wealth, and Happiness. New Haven: Yale University Press.

Thaler R.H. (2000) From Homo Economicus to Homo sapiens // Journal of Economic Perspectives, vol. 14, no. 1, pp. 133-141. 
Thaler R.H., Shefrin H.M. (1981) On Economic Theory of Self-Control // Journal of Political Economy, no. 2, pp. 392-406.

Tietzel M., Muller C. (1998) Noch mehr zur Meritorik // Zeitschrift für Wirtschafts - und Sozialwissenschaften. Berlin: Duncker \& Humblot.

Tsebelis G. (1990) Nested games: rational choice in a comparative perspective. Berkeley: University of California press.

Tsebelis G. (1995) Decision making in political systems: veto players in presidentialism, parliamentarism, multicameralism, and multipartyism // British journal of political science. Cambridge. No. 25. P. 289-326. 